\title{
OESTERHELD Y SUS ALEGORÍAS DEL FUTURO ${ }^{1}$
}

\author{
OESTERHELD AND HIS ALLEGORIES OF THE FUTURE
}

Ricardo Haye ${ }^{2}$

El ensayista francés Francis Lacassin, que se especializó en el estudio de la cultura popular, no ha sido el único en formular consideraciones de valoración positiva respecto de las historietas. Pero fue él quien acunó la fórmula del "noveno arte" para referirse a los comics. Sin embargo, todavía podría ocurrir que a alguien le resulte incómodo situar a las historietas en el campo de la literatura.

Es que el debate académico no se clausuró aún por obra y gracia de quienes menosprecian al comic y a la llamada novela gráfica y los consideran apenas como subproductos culturales.

Seamos justos: algunas expresiones del comic difícilmente alcancen nunca el Olimpo de las obras consagradas... Pero con criterio similar deberíamos considerar que también existen libros que nos daría vergüenza situar en ese contexto de gloria.

Este ensayo está centrado en la obra del autor argentino Héctor Germán Oesterheld, que se destacó como guionista de historietas y que también escribió novelas y numerosos relatos breves.

A mediados del siglo XX, en la Argentina la producción de historietas no lograba escapar a la lógica comercial mayoritaria. Laura Vázquez sostiene que el conflicto de esa época "puede traducirse del siguiente modo: por un lado, la pretensión de que la historieta tuviera la tutela del arte, y, por el otro la defensa de los valores de la cultura de masas".

1 Originalmente apresentado durante as XIII Jornadas Andinas de Literatura Latinoamericana, na cidade de Rio Branco, Acre, campus da Universidade Federal do Acre, em agosto de 2018.

2 Doctor en Comunicación Audiovisual en la Universidad Autónoma de Barcelona y docente e investigador en la Universidad Nacional del Comahue (Argentina). 
Oesterheld no renegaba de la masificación de la historieta, pero tampoco la concebía como un bien de consumo alejado del arte. La autora que citamos consigna que un "programa renovador" comenzaría a forjarse mediante una articulación creativa entre lo estético y lo narrativo que intentaba despegarse de las formas industriales, masivas y estandarizadas y dejar de alentar el consumismo alienante de las sociedades de masas. En el caso específico del autor que concentra nuestro interés, esos propósitos resultaban coincidentes con su concepción ideológica.

El creador reconocía la fuerte atracción que le provocaba la ciencia ficción. En la entrevista que Carlos Trillo y Guillermo Saccomano le realizaron para su ensayo Historia de la Historieta Argentina, Héctor explicaba que con la ciencia ficción "Se puede decir muchas cosas, se puede metaforizar, aludir poéticamente a lo de todos los días". Como veremos luego, las metáforas y las alusiones poéticas no siempre fueron sutiles y a veces rozaron lo panfletario.

En cualquier caso, desde sus creaciones más tempranas Oesterheld nunca disimuló su pensamiento político y las críticas y cuestionamientos al capitalismo, el imperialismo y el colonialismo fueron ganando intensidad con el correr de los años. El compromiso ideológico que lo animaba no amainó ni siquiera con la llegada de la última dictadura que asoló la Argentina. El régimen genocida instalado en marzo de 1976 no solo fue el responsable de su desaparición forzada, sino también de la de sus cuatro hijas, dos de las cuales estaban embarazadas, y dedos yernos.

Oesterheld se graduó como geólogo y esa vocación científica le abrió una puerta a la escritura, ya que varios de sus textos tenían el propósito de aportar a la divulgación de la ciencia. No obstante, la ficción pronto fue ganando su atención y su interés. La ciencia no estaba clausurada, sino que - por el contrario - abastecía su labor de escritor. Si bien los primeros relatos tuvieron como destinatarios a los niños, pronto extendió los contornos de sus seguidores y en esa expansión mucho tuvieron que ver algunos de sus personajes más populares, como Bull Rocket, el Sargento Kirk o Ernie Pike, creados a comienzos de los años 50 del siglo pasado.

De cualquier manera, todos los análisis coinciden en que su trabajo más significativo fue "El eternauta", cuyos guiones de la segunda parte 
debió concluir desde la clandestinidad en la que había ingresado por su adhesión al grupo guerrillero Montoneros.

Antes de concebir la que sería su obra cumbre, Oesterheld había experimentado con "Rolo, el marciano adoptivo". Algunas características se repiten en ambos trabajos: son historias donde la ciencia ficción se hibrida con la aventura y no existe la figura del héroe profesional, el sujeto acostumbrado a las correrías intrépidas. Rolo no es más que un maestro de barrio y Juan Salvo, en la obra canónica, es un hombre joven aficionado a jugar a las barajas con sus amigos por la noche en su bohardilla-taller.

Puede ser que años después, en un continuo temporal muy distinto de aquel del que partió, Salvo adquiriera características cósmicas y que incluso se le endurezca la piel como fruto de sus peripecias siderales.

Pero, en el origen, los dos - Rolo y él-eran sujetos comunes envueltos en historias sorprendentes. En sus mundos ordinarios predominaban las rutinas; no eran viajeros consumados sino hombres de hogar que, sin proponérselo, debieron enfrentar epopeyas astrales.

Queremos detenernos en "El eternauta", la historieta que originalmente publicó la revista Hora Cero Semanal entre 1957 y 1959 y que, a partir de entonces, conoció varias secuelas y un gran número de reediciones. La trama de la historia de Oesterheld fue llevada a la ilustración por el dibujante Francisco Solano López.

Vamos a señalar algunas de las particularidades del comic.

La primera es que Héctor Germán Oesterheld producía novedades. Una de ellas fue arrebatarle a la cultura sajona del comic la exclusividad de las locaciones de sus historias de ciencia ficción. El relato de "El eternauta" no transcurre en Washington, Nueva York ni en ninguna otra metrópoli norteamericana. Los acontecimientos que se narran suceden en las calles de Buenos Aires. Las viñetas retratan algunos de sus lugares emblemáticos y reconocibles: la plaza de los dos Congresos, las barrancas de Belgrano, el estadio de fútbol de River Plate, Plaza Italia o la avenida General Paz.

Por primera vez, una obra de ciencia ficción desafía el lugar común de los escenarios primermundistas y elige locaciones de un arrabal del planeta.

Por otra parte, sus relatos no están situados en futuros lejanos o 
indeterminados, sino que posibilitan una familiaridad o identificación que reposa sobre marcas de época que pueden señalarse con toda precisión.

Un claro ejemplo se advierte en las imágenes donde se cuelan símbolos anclados profundamente en el imaginario argentino. Entre ellos se destaca el grafiti de "Perón vuelve" que acompañó los 18 años de proscripción del movimiento político derrocado en 1955. Y otro más es la pintada callejera que se refiere a Frondizi, el presidente que gobernaba la Argentina en los años en que Oesterheld y Solano López desarrollaban su historia.

También constituyó una singularidad la añadidura de otras lecturas posibles a relatos que acostumbraban a agotarse rápidamente en sí mismos o que subliminalmente transmitían una visión hegemónica del mundo, funcional a los intereses de los sectores dominantes.

"El eternauta" denuncia que los desheredados de la Tierra constituyen el sector más vulnerable, pues los países poderosos se encargan de negociar su propia seguridad mientras se desentienden de la suerte que las restantes naciones puedan correr a manos de los invasores alienígenas. A cambio, plantea que incluso los extraterrestres presentan un sistema de castas más y menos privilegiadas en cuya base se encuentran unos escarabajos enormes. Estos "cascarudos" no son más que la fuerza operativa de los genuinos invasores, quienes los controlan mediante aparatos incrustados en su cerebro que los obligan a cumplir las directivas de sus superiores. Apenas por encima de ellos están los gurbos y los Manos. Todos son, apenas, títeres de los Ellos, nunca entrevistos, que controlan todo a distancia y no arriesgan nada, salvo la vida de sus marionetas.

Oesterheld evitaba el individualismo extremo y el mesianismo en la construcción de las figuras heroicas. Toda la solidaridad que las sociedades favorecidas mezquinaban al resto del mundo se hacía presente en el héroe grupal de su historia:

El héroe verdadero de El Eternauta - escribió Héctor en el prólogo de la historieta - es un héroe colectivo, un grupo humano. Refleja así, aunque sin intención previa, mi sentir íntimo: el único héroe válido es el héroe 'en grupo', nunca el héroe individual, el héroe solo. Quizás por esta falta de héroe central, El Eternauta es una de mis historias que recuerdo con más placer. 
El propio autor reconoció una poderosa influencia: la del Robinson Crusoe de Daniel Defoe. También "El eternauta” plantea la condición de un hombre rodeado o preso, pero ya no por el mar sino por la muerte. Solo que Juan Salvo, el equivalente de Robinson, no está solo sino rodeado por su familia y sus amigos.

Ese acompañamiento prefigura el que los grupos familiares de Hijos de desaparecidos, Madres y Abuelas de Plaza de Mayo sostendrán empecinadamente años más tarde en la confrontación con un enemigo terrenal, pero tan cruel y sanguinario como los alienígenas invasores.

La obra de Oesterheld se revela profética y anticipa acontecimientos que, en la realidad, sobrevendrían recién veinte años más tarde cuando fuerzas de ocupación militar con apoyo civil arrasaron la institucionalidad argentina.

En este sentido, "El eternauta" reconvierte la alegoría tantas veces empleada en una infinidad de historietas, películas y seriales de televisión estadounidenses: cualquiera que no participe de la condición de WASP (blanco, anglosajón y protestante) es una amenaza. Para una gran cantidad de relatos norteamericanos el peligro encarnó sucesivamente en los indios, los rusos, japoneses o musulmanes; ellos fueron ese otro, el distinto que venía a poner en riesgo la continuidad de su modo de vida y, quizás también, la subsistencia de los privilegios. Claramente, la construcción de estos antagonistas estaba regulada por conceptos estereotipados y rigurosamente esquemáticos, que presentaban personajes sin claroscuros ni contradicción alguna: eran perversamente malos.

A Oesterheld, la anécdota de superficie de una invasión extraterrena le sirvió de pantalla para proyectar un ideario que abogaba por la unidad de las naciones subdesarrolladas y pintaba severamente el retrato de las potencias imperiales.

Más allá del anticipo de los sucesos luctuosos que mi nación iba a vivir con la última interrupción del orden democrático, existe un dato menor en el que se destaca una curiosa manifestación anticipatoria: una de las viñetas de "El eternauta" mostraba el estadio Monumental de Núñez

perteneciente al club River Plate tal como se lo ve hoy. Sin embargo, en 1957 la cabecera que da espaldas al Río de La Plata aún tenía incompleta 
la construcción de la segunda bandeja de su tribuna. Esa obra recién se terminó para el Mundial de Fútbol del año 1978, más de 20 años después. En este caso, todo el mérito fue del dibujante Francisco Solano López que, en el libro "Solano López en primera persona”, opinaba que "además de una historia de ciencia ficción fue un ejercicio de anticipación de la entrega que el país iba a vivir décadas después”.

El periodista y escritor Juan Sasturain considera que "El eternauta" es el mejor relato de aventuras que ha dado la Argentina y el mito más perdurable que creó la narrativa de mi país en la segunda mitad del siglo XX.

El filósofo Horacio González, ex director de la Biblioteca Nacional Argentina escribió:

Es la Buenos Aires de 1958, con inscripciones en las paredes que exhiben demasiado la intención del artista de decir: esto es hoy, en esta actualidad me disuelvo, en este tiempo presente cuya pesadez me abarca, hago el esfuerzo de fijar un momento de su flujo perpetuo, flujo que pide que mis ojos estén situados en exacta contemporaneidad.

Y luego concluye:

El Eternauta es la más importante alegoría política argentina. Se sostiene como molde atemporal, y lucha contra todos los elementos temporales que ella misma contiene (esa Buenos Aires real) sin que sepa cómo será el desenlace. Oesterheld jugó a ese combate. O las alegorías están para contar la historia sirviendo de carril a los acontecimientos vivos, sin desaparecer nunca como relato, como arquetipo y como sueño del lector universal. O lo contrario: la historia viva las hace estallar. El Eternauta es la historieta pensada con el dulce contraste de una "eternidad argentina" sólo resoluble en luchas territoriales reales, que al final, ocurren.

En 1970, Oesterheld retoma similares preocupaciones cuando da forma a la trama de "La Guerra de los Antartes". Esta historia tuvo dos ediciones. La primera apareció en la revista 2001 en 1970 y contó con los dibujos de León Napo. La segunda edición fue publicada por el diario Noticias, en 1974 y su ilustrador fue Gustavo Trigo.

La historieta cuenta que la Tierra vuelve a ser invadida por seres de otro planeta. Pero, tal como refleja su trayectoria narrativa, aquí el relato es 
más explícito aún respecto de la confabulación entre las grandes potencias y los alienígenas a fin de sojuzgar a los países menos desarrollados.

Ese derrotero ya se había hecho evidente en la versión de "El eternauta" que la revista Gente comenzó a publicar en 1969. Allí, Juan Salvo se pregunta: “¿Cómo es que los grandes países nos abandonaron así?”. Favalli, realista y ácido, le responde: “¿De qué te extrañás, Juan? Los grandes países nos tuvieron siempre atados de pies y manos. Antes, el invasor eran los grandes consorcios. Sus nevadas mortales eran la miseria, el atraso, nuestros pequeños egoísmos manejados desde afuera”.

Sin dudas, esto era mucho más de lo que una publicación tan conservadora como Gente podía tolerar y la revista no solo terminó por precipitar el fin de la historieta, sino que, además, ofreció a sus lectores una carta de su director disculpándose por haberle dado semejante plato indigesto a los lectores.

Un detalle muy significativo: mientras en "El eternauta" la organización de la resistencia cuenta con el aporte relevante de un académico (el Profesor Favalli), en "La guerra de los Antartes" la mayor responsabilidad recae en un militar. Si por un lado puede leerse como la esperanza del surgimiento de una corriente comprometida con los intereses populares entre los uniformados, también es posible interpretar que esa decisión remite al carácter militarizado de la organización Montoneros, a la que Oesterheld había adherido.

Lo cierto es que esta historieta pivotea entre escenarios utópicos y distópicos. Obviamente, la distopía es producto de la invasión extraterrestre, pero la utopía se asienta en el hecho de que la Argentina que enfrenta a los Antartes es un país en el que triunfó una revolución que expresa el imaginario de la izquierda peronista.

Ahora que ha pasado el tiempo, además de constituirse en base y fuente de fabulaciones, la obra de Oesterheld puede estudiarse como forma comunicativa que sirve para la indagación existencial, la reconstrucción de la memoria, la lectura alegórica y la anticipación/revisión de la historia.

En numerosas ocasiones se mencionó la posibilidad de que El Eternauta llegase al cine, pero eso nunca ocurrió. En cambio, sí se realizó una adaptación radiofónica novelada cuyos 22 episodios transmitió LS 11 
Radio Provincia de Buenos Aires, en 2011. Por otra parte, en 2010, un grupo de artistas plásticos patagónicos montó una exposición colectiva que situaba la invasión alienígena en el Alto Valle del Río Negro, lo que constituyó una temprana manifestación de narrativa transmedial.

En Oesterheld, el geólogo devenido guionista, las historias fueron canales de expresión para sus ideales humanitarios delibertad, así como para denunciar el avasallamiento y la dependencia. Sus historietas poseen siempre una fragancia de aventura que, por momentos, llega incluso a volverse más significativa que la de ciencia ficción.

En cambio, la poética de sus cuentos gira decididamente en torno a la ficción científica. En ejemplo más luminoso es el libro "Más allá de Gelo" que, muchos años después de la desaparición y muerte de Héctor, vio la luz gracias a la indagación minuciosa de Mariano Chinelli y Martín Hadis entre los papeles personales del autor.

La recopilación de relatos ofrece un muestrario de humanidad y lirismo que se hace presente desde el mismo cuento que abre el volumen, titulado "El árbol de la buena muerte".

El relato muestra la vida de una familia de colonos en Marte. La madre, el padre y un hijo de catorce años, viven junto a la madre de la mujer. María Santos es muy mayor ya y extraña los paisajes entrañables de su tierra de origen: Catamarca, provincia argentina recostada contra la cordillera. El texto de Oesterheld plantea un fuerte contraste entre un futuro en el que la humanidad se ha expandido más allá de la Tierra y un pasado que brota en forma de imágenes en la memoria de María: calles de tierra, veredas de ladrillos torcidos, chicos de guardapolvo jugando a la bolita y el esqueleto de un barrilete que no termina de morirse nunca, enredado en un cable telefónico. Uno se pregunta ¿cómo conciliar esos extremos de un salto temporal que parece de siglos? Pero cuando esos interrogantes aún no fueron despejados, la vida de María se apaga bajo un árbol que le adormece la conciencia con recuerdos gratos. Solo el nieto parece descontento y es el único que repara en que "En tiempos de la Abuelita la gente se moría sabiendo, y había últimas palabras, dolor, agonía; la muerte era la muerte, la gente se moría de verdad. Ni eso nos dejan ahora". 
El segundo cuento es "Una muerte" y presenta la armoniosa convivencia de un humilde pajarero y un ser de otro mundo que descubren en las aves un poético punto de encuentro entre sus respectivas especies.

Luego viene el cuento "Un extraño planeta, planeta... planeta", en el que Oesterheld pone en juego destrezas descriptivas auspiciadas por su conocimiento de ciencias. Los acontecimientos ocurren en Sigma 9, un planeta bañado por la luz azulada de un sol doble y cuya atmósfera posee demasiado contenido de flúor.

El texto abunda en vívidas imágenes que se refieren a plantas azules con flores inmensas cuyos pétalos ondulan constantemente y arbustos rojizos que, cuando uno los toca, emiten una serie de sonidos extraños, en curiosa armonía.

A ese entorno bucólico llegan los primeros hombres y el fracaso de su intento de establecerse recuerda inmediatamente a las primeras expediciones terrestres que narró Bradbury en "Crónicas marcianas". Sin embargo, la mayoría de los cuentos de "Más allá de Gelo" se caracterizan por la impronta propia de un autor singular.

Un hombre sensible y comprometido, estragado por la barbarie de un régimen monstruoso pero incapaz de doblegarlo, a pesar de la soledad y la muerte que le fueron impuestas y que él siempre procuró evitarle a las criaturas de su imaginación.

\section{Referencias}

CHINELLI, M.; HADIS, M. Más allá de Gelo. Buenos Aires: Editorial Planeta, 2014.

GONZÁLEZ, H. La alegoría feliz. En Revista El juguete rabioso. Buenos Aires, 2007.

LACASSIN, F. Pour un neuvième art: la bande dessinée. París: Union Generale d'Editions, 1971.

SOLANO LÓPEZ, F. Solano López en primera persona. Buenos Aires: Doedytores, 2002.

TRILLO, C.; SACCOMANNO, G. Historia de la Historieta Argentina. Buenos Aires: Ediciones Record, 1980.

VÁZQUEZ, L. El oficio de las viñetas. La industria de la historieta argentina. Buenos Aires: Paidós, 2010. 